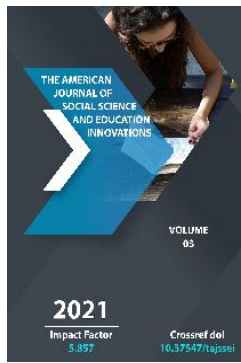

\title{
Artistic Interpretation Of Wedding Ceremonies In Uzbek Folk Epics (As An Example Of “Alpomish" Epic)
}

\author{
Latifa Avazovna Khudaykulova \\ Candidate Of Philological Sciences, Senior Researcher Of Institute Of Uzbek Language, \\ Literature And Folklore Of The Academy Of Sciences Of The Republic Of Uzbekistan
}

\begin{abstract}
Journal Website:
http://theamericanjour

nals.com/index.php/taj

ssei

Copyright: Original content from this work may be used under the terms of the creative commons attributes 4.0 licence.
\end{abstract}

\section{ABSTRACT}

This scientific article describes the epic interpretation of the wedding in "Alpomish" epic and the folklore, customs and regional features of the wedding ceremony.

\section{KEYWORDS}

Epic, tradition, ceremony, wedding, tradition, folklore.

\section{INTRODUCTION}

Marriage is a tradition that embodied universal values, occurred in the last period of primitive society and later took a legalized ritual form in writing. "Marriage" is an Arabic word and means "couple's legalization through sharia", "family union" ${ }^{1}$. The first records of the wedding ceremony are mentioned in the work of the great linguist of the XI century Makhmud Kashgari "Devonu lugotut-turk" and explained a number of words related to the wedding ${ }^{2}$.

\footnotetext{
${ }^{1}$ Annotated dictionary of the Uzbek language. Two volumes. T.1. - M.: Russian, 1981. - p.502.

2 Mahmud Kashgari. Devon of Turkish words (Devonu lugotit turk).T. II, III. - T., 1960-1961.
}

Nowadays, some ancient members of Uzbek wedding folklore have been forgotten, many

traditional genres continue to live in live performance state.

Most traditional poetic folklore, such as "the skirt tearing" the engagements of young children from the cradle", "yor-yor", "bride's bow", "irga tagi", "bride sitting", "groom sitting", "asking for empowerment", "nine plates", "breast returning", "wedding applause", "face opening" in wedding ceremonies held in all regions of Uzbekistan, still retain their ancient features. 
These ancient traditions and customs of our people are reflected in Uzbek folk epic "Alpomish".

In "Alpomish" epic written by Kara Bakhshi Umirov version, the children marriage custom as "skirt tearing" is described as follows: «Khizr named "Boybori's son Khakimbek and Boysari's daughter Barchinoy. He slapped Khakimbek on his shoulder, and five paws marks were stained. He took the two babies on two knees and marked them both, he grabbed Hakimbek and Barchinoy's back skirt together and tore it, engaged the two as a 'torn skirt'».3

From ancient times, when a child is born in Uzbek family, parents worry about his happiness and future, therefore, those who have given birth to a son, if they have a daughter by one of their close relatives or acquaintances, intend them to each other from childhood. The two family members intend to get engaged when their children grow up, and when when the girl is cradled for the first time, the boy's parents puts on a sewn shirt for the girl.

Popularly known as the skirt tearing, the engagements of young children from the cradle, ear biting customs were often performed at the "Cradle wedding" ceremony held in the family where the girl was born. In Andijan region, a man who had given birth to a boy cut a small part of the girl's cradle with a knife and thus this girl was considered 'became possessed' from a young age. ${ }^{4}$

\footnotetext{
${ }^{3}$ Murodov M., Khakimov N., Ergashev A. Valuation. Book 1.- Tashkent: Literature and art, 2001. - p.3536.

${ }^{4}$ Joraboev A. Names of wedding ceremonies in Uzbek language (on the basis of Andijan group
}

Ethnographer K.Shoniyozov, commenting on the wedding customs of the Karlyk, writes: " After the bride is chosen, two women from the groom's side - the groom's aunts or married sister - go to the matchmaking. Before entering the nomadic wagon they say "we have come to slavery!". The girl's mother welcomes them. A table is set in front of the matchmakers and while drinking tea, one of the matchmakers reveals the purpose».

In "Alpomish" epic this tradition is reflected when Karajon's mother went to Barchin as a matchmaker. Barchin says the old woman Surkhayil, who went to matchmaking:

Қозонда қайнаган ширбоз гўшмиди,

Шу қизингнинг агар боши бўшмиди?

Боши бўшми дейин, сендан сўрайин,

Келин қилиб бошига рўмол ўрайин,

Қоражонга аташтириб борайин.

Мехмон бўлиб бирор гузарим тушди,

Итинг кўn талади, кўп нашам учди.

Шул қизингни кўриб кўнглим хушдир,

Албатта қизингнинг бул боши бўшдир.

Бойбича, эшитгин айтган сўзимди,

Кўнглинг бўлиб, хафа қилма ўзингди,

Келин қилиб кетай сенинг қизингди,

Сенинг қизинг Қоражонга лозимдир 5 .

dialects): diss.cand.philol.sciences. - Tashkent, 1971. - p.158.

${ }^{5}$ Alpomish. Uzbek folk art. - Tashkent: Literature and art, 1979. - p.37. 
Apparently, when the Kalmyk wrestler Karajon's mother went to Barchin as a matchmaker and asked: «ls yhis girl free?». At this point, the phrase "empty-headed" means that the girl was not engaged by anyone, 'wrap the scarf' accumulation was used to "keep her head busy", i.e. a symbolic expression of engaging.

The day before the main part of the wedding, the groom with his friends and close relatives came to the girl's house. On that day, before the marriage ceremony, the custom of "asking for an empowerment" was performed at the girl's house. In this case, the girl was supposed to give her empowerment to her uncle. The groom gave sarpo (clothes) and money to the empowerment. After that, the bride was considered eligible for marriage. The custom of "asking for an empowerment" lasted until dawn. After this, in the morning the bride gave her empowerment to her uncle and the mullakh to marry the bride and groom. ${ }^{6}$

These traditions have been preserved in some places, for example, in the villages of Zaamin district, according to scientific sources ${ }^{7}$. This ancient tradition of our people is reflected in Uzbek folk epic "Alpomish". Fozil Yuldash ogli, a well-known bakshi (folk singer) living in Loyka village in Bulungur, describes Alpomish and Barchin wedding, telling about wedding customs of his fellow villagers one by one:

Барчинойни бул ўртага олади,

\footnotetext{
${ }^{6}$ Folklore archive of the Institute of Language and Literature named after Alisher Navoi of the Academy of Sciences of the Republic of Uzbekistan.Inv. №1833. - p.9-10.

7 Toychiboev B., Kashkirli K. Zaamin's language encyclopedia.- Tashkent: Akademnashr, 2012. p.33.
}

қадимги расими шундай бўлади:

Барчинойни қиз опқочди қилади,

Не келинлар юриб қизни сўради,

Бир ердан буларни топиб олади.

Икки вакил у мулладан келади,

Келиб қизнинг ихтиёрин сўради,

Уялгандан қабул қилмай туради.

Қиз суйлатар деган расим бўлади,

Қиз гапиртган анча пулни олади.

Барчин вакилини энди беради,

Хакимбекни энди қабул қилади...

The teacher asks the representatives, they also get something to testimony, the mullakh recites the khutbakh and marries, the delegates also accepted the mullah's request and returned. He asks Khakimbek for some conditions and accepts them on condition, all were happy and he returned to his time ${ }^{8}$.

In the past, the matchmaker who found out where the girl was "hiding" gave various gifts, sweets, coins to the bride's friends and brought bride to "godfather" to marry.

During the "nine dishes" ritual, which took place in the second stage of the wedding, the bridegroom and his friends were entertained in a specially prepared room in the bride's house. According to tradition, this custom was

8 Monuments of Uzbek folk art. Volume 1 "Alpomish (Uzbek folk heroic epic). Narrator: Fozil Yuldash ogli. Prepared by: Kh.Zarifov, T.Mirzaev. Tashkent: Gafur Gulom publishing house, 2015. p.205. 
called "nine plates" in the oasis because nine different dishes were served to the bridegroom's table. ${ }^{9}$

Therefore, the linguist B.Tuychibaev notes that the customs described in "Alpomish" as groom friends, making nine plates, putting money on nine plates, lighting a fire in the middle, greeting the bridegroom when he goes to the bride are also preserved in Kipchak Uzbeks until recently». ${ }^{10}$

This tradition is also reflected in "Alpomish"epic interpreted by Fozil Yuldash ogli described as:

Бойваччалар бекнинг гирдин олади,

Куёв нўкар бўлиб бунда туради.

Ўзбекнинг расими шундай бўлади:

Қизу жувон бари йиғилиб келади,

Аёллари туцққиз товоқ қилади,

Куёвнинг олдига шундай боради,

Опборган таомин нўкарлари еб,

Товоғига танга-тилла солади,... ${ }^{11}$.

In "yor-yor" written by ethnographer A.Ashirov, the heroes' names of "Alpomish" epic, which are widely used in the oasis repertoire, as well as the "ulan" of the

\footnotetext{
${ }^{9}$ See the "Nine plates" tradition: Juraev M. The secrets of nine// Mysterious world. Collection 3. Tashkent, 1986. - p.48-55.

${ }^{10}$ Toychiboev B. "Alpomish" and the vernacular. Tashkent: Science, 2001. - p.31.

${ }^{11}$ Alpomish. Uzbek folk art. - Tashkent: Literature and Art Publishing House, 1979. - p.160.
}

kongirot living in Surkhandarya oasis, give the text a local character:

Ок ўтовнинг бекаси,

Барчин чечам, ёр-ёр,

Ойдин-ойдин осмонлар,

Ойдин кечам, ёр-ёр.

Ойдин-ойдин осмонлар,

Ойдин кечам, ёр-ёр,

Ўзбек элим қизлари,

Жони дилим, ёр-ёр.

According to ethnographer A. Ashirov, texts of "yor-yor" genre are called ulan (song, usually a wedding song).

In conclusion, it should be noted that the folklore of Uzbek wedding ceremony is distinguished by the fact that it has certain local features arising from the ethnic composition, historical and cultural traditions, Uzbek population lifestyles and customs. In many customs interpretation, such «matchmaking», «cutting the bread», « engagement celebrations», " groom testing», " turns around the fire ", "bride's bow (a ceremony where the young wife bows to her husband's relatives in the morning)", "face opening (the visit of the relatives of the young husband on the day after the wedding)», " dog growl», " the old woman died», " window displays», " hair wiping» in the wedding, there are signs that are common to all Uzbek folklore. At the same time, the songs and sayings performed during the existing traditions performance in Uzbek folk epic "Alpomish", i.e. the verbal part interpretation, 
show the originality of Uzbek ceremonial folklore.

\section{REFERENCES}

1. Annotated dictionary of the Uzbek language. Two volumes. T.1. - M.: Russian, 1981. - p.502.

2. Mahmud Kashgari. Devon of Turkish words (Devonu lugotit turk).T. II, III. - T., 1960-1961.

3. Murodov M., Khakimov N., Ergashev A. Valuation. Book 1.- Tashkent: Literature and art, 2001. - p.35-36.

4. Joraboev A. Names of wedding ceremonies in Uzbek language (on the basis of Andijan group dialects): diss.cand.philol.sciences. - Tashkent, 1971. - p.158.

5. Alpomish. Uzbek folk art. - Tashkent: Literature and art, 1979. - p.37.

6. Folklore archive of the Institute of Language and Literature named after Alisher Navoi of the Academy of Sciences of the Republic of Uzbekistan.Inv. №1833. - p.9-10.

7. Toychiboev B., Kashkirli K. Zaamin's language encyclopedia.- Tashkent: Akademnashr, 2012. - p.33.

8. Monuments of Uzbek folk art. Volume 1 "Alpomish (Uzbek folk heroic epic). Narrator: Fozil Yuldash ogli. Prepared by: Kh.Zarifov, T.Mirzaev. - Tashkent: Gafur Gulom publishing house, 2015. - p.205.

9. See the "Nine plates" tradition: Juraev $M$. The secrets of nine// Mysterious world. Collection 3. - Tashkent, 1986. - p.48-55.

10. Toychiboev B. "Alpomish" and the vernacular. - Tashkent: Science, 2001. p.31.
11. Alpomish. Uzbek folk art. - Tashkent: Literature and Art Publishing House, 1979. - p.160. 